\title{
Cladocera Community Composition as a Function of Physicochemical and Morphological Parameters of Dystrophic Lakes in NE Poland
}

\author{
Edyta Zawisza $^{1}$ - Izabela Zawiska ${ }^{2,3}$ - Alexander Correa-Metrio ${ }^{4}$ \\ Received: 5 February 2016/Accepted: 27 September 2016 / Published online: 12 October 2016 \\ (C) The Author(s) 2016. This article is published with open access at Springerlink.com
}

\begin{abstract}
Cladocera are one of the most important freshwater biological indicators for a wide range of environmental variables. They show strong responses to several environmental factors (e.g., trophic state, water depth, temperature) and are very sensitive to changes in water $\mathrm{pH}$. The main interest of this study was to evaluate the relationship between subfossil Cladocera community composition and environmental properties of dystrophic lakes $(\mathrm{pH}$, water transparency, conductivity, dissolved oxygen, depth and area). We hypothesize that Cladocera species composition depends on a dystrophication index (HDI); thus, Cladocera assemblages change with the degree of dystrophication. For the study, we selected a group of dystrophic lakes located in Wigry National Park (WNP), NE Poland, where we found subfossil remains of 24 Cladocera species belonging to four families (Chydoridae, Bosminidae, Daphniidae, and Sididae). A non-metric multidimensional scaling (NMDS) was used to elaborate on the similarities
\end{abstract}

Electronic supplementary material The online version of this article (doi:10.1007/s13157-016-0832-x) contains supplementary material, which is available to authorized users.

Edyta Zawisza

ezawisza@twarda.pan.pl

1 Institute of Geological Sciences, Polish Academy of Sciences, Research Centre in Warsaw, INGPAN, Twarda 51/55, 00818 Warsaw, PL, Poland

2 Institute of Geography and Spatial Organization, Polish Academy of Sciences, Twarda 51/55, 00818 Warsaw, PL, Poland

3 GFZ German Research Centre for Geosciences, Section 5.2, Climate Dynamics and Landscape Evolution, Telegrafenberg C, D-14473 Potsdam, Germany

4 Instituto de Geología, Universidad Nacional Autónoma de México, Ciudad Universitaria, 04510 Ciudad de Mexico, Mexico among samples in cladoceran-community composition and structure. Statistical analyses showed that Cladocera assemblages in all the studied lakes were similar, and individual Cladocera species respond to the measured environmental parameters (e.g., pH, lake size and depth). Our results suggest that in dystrophic lakes, Cladocera community composition is an emerging characteristic of individual species responses to the environment.

Keywords Dystrophic lakes · Cladocera · Boreal lakes · Wigry national park

\section{Introduction}

One of the most important zooplankton components in freshwater lake environments are Cladocera (Crustacea). They are common throughout the world, from high to low altitudes; from tropical to temperate areas; in shallow and deep lakes of all sizes; and in alkaline, neutral and acidic conditions, among other environmental gradients. However, taxa specificity regarding environmental conditions makes cladocerans important biological indicators for a wide range of environmental variables (Chen et al. 2010; Rumes et al. 2011). Cladocera show a strong response to environmental factors, such as trophic state (Szeroczyńska 1991, Zawisza and Szeroczyńska 2007; Chen et al. 2010), total phosphorus concentration (Brodersen et al. 1998; Amsinck et al. 2005; Chen et al. 2010), water depth (Korhola et al. 2005; Nevalainen 2011; Gałka et al. 2014), temperature (Lotter et al. 1997; Korhola 1999; Mirosław-Grabowska and Zawisza 2013; Zawiska et al. 2015), etc. Cladocera species are especially responsive to changes in $\mathrm{pH}$, reflecting their sensitivity to acidification (Locke and Sprules 2000; Nevalainen et al. 2013; Zawiska et al. 2013). 
Cladocera are also one of the most important zooplankton groups inhabiting dystrophic lakes, and they likely represent the most important paleobioindicator for this type of environment. Dystrophic lakes are common in the boreal zone (e.g., Scandinavia, Russia, Canada) and rare in the Middle European Lowlands. In Poland, they occur in the coldest NE lowlands, at the Wigry National Park (WNP), where climate is similar to the boreal region. Polish dystrophic lakes located within the WNP are surrounded by pine-spruce forest that makes the landscape resemble the Scandinavian region (Drzymulska and Zieliński 2013). The local name of these dystrophic lakes is "suchary", which in Polish means "poor at life".

Dystrophic lakes are described as natural and immutable ecosystems (Drzymulska et al. 2013; Zawiska et al. 2013). These water bodies have several distinctive features, notably, high amounts of organic acids, brown-coloured water, acidic water, low visibility and conductivity. Their extraordinary environmental character is confirmed by their protective status under the law (National Park, Nature Reserve, Natura 2000 network), although their limnological classification is still debated (Jones 1992; Drzymulska and Zieliński 2013). One of the best descriptions of their hydrological and limnological characters is the HDI (Hydrochemical Dystrophy Index) (Górniak 2006). This dystrophication index takes into account water $\mathrm{pH}$, conductivity and DOC/DIC ratio; lakes with an HDI value higher than 40 are considered dystrophic (Górniak 1996, 2006; Keskitalo and Eloranta 1999). In the area of WNP, dystrophic lakes are associated with an HDI ranging from 45 to 121 (Górniak 2006; Zawiska et al. 2013). This wide range reflects a high variability of hydrochemical conditions in the lakes and represents a starting point for our Cladocera study. We hypothesize that Cladocera species composition depends on HDI value and that Cladocera assemblages change with degree of dystrophication.

Little is known about Cladocera species composition from dystrophic lakes of WNP. By the end of the twentieth century, several freshwater zooplankton studies had been conducted (e.g., Tunowski 1992, Górniak and Dobrzyń 1999, Karabin 1999, Karabin and Ejsmont-Karabin 1999, Kozłowska 1999). These studies reported Cladocera species richness ranging from one (Tunowski 1992) to a few species (Górniak and Dobrzyń 1999; Karabin 1999). This information led us to conduct a palaeolimnological study of Lake Suchar IV, where we found the remains of 14 Cladocera species (12 from family Chydoridae, 2 from Bosminidae), whereas previous studies of recent zooplankton in the same lake reported only two (Tunowski 1992), six (Karabin 1999), or up to nine species (Górniak and Dobrzyń 1999).

The main objective of this study was to determine the environmental factors that govern the distribution of Cladocera fauna in the dystrophic lakes.

In this paper, we (1) explore the relationship between Cladocera fauna composition and HDI values and, therefore, lake dystrophication state; (2) report information about environmental demands of cladoceran communities at the studied lakes; and (3) create an inventory of the main Cladocera species that inhabit aquatic ecosystems of the dystrophic lakes of interest. It was also important to determine a specific composition of Cladocera fauna for dystrophic lakes. This knowledge will enhance precision in palaeoclimatic and palaeoecological reconstructions, especially while tracking dystrophication phases in the history of lakes, and will contribute to a better interpretation of fossil Cladocera data from sediments of various other lakes.

\section{Study Site}

The study area is located in NE Poland, near the city of Suwałki (Fig. 1). The unique flora, fauna, and landscape of this area are protected by law since 1989, when the WNP was created. The park area lies within the range of the Pomeranian Phase of the Weichselian glaciation (Marks 2002), within the Lithuanian Lakeland region (Kondracki 1994). Most of Poland is characterized by a climate that belongs to group $\mathrm{D}$ - continental/microthermal climates (McKnight and Darrel 2000). However, the NE region of the country is characterized by environmental conditions similar to those in northeastern Europe and southern Finland, representing the most severe climatic conditions within the Polish lowlands. The mean annual air temperature and precipitation are $5.3{ }^{\circ} \mathrm{C}$ and $593 \mathrm{~mm}$, respectively (Grabowska-Bajkiewicz 1997). The winter lasts around four and a half months, with a mean temperature of between -6.7 and $-2.7{ }^{\circ} \mathrm{C}$. Ice-cover length is approximately 3 months, from the end of December until the end of March. The vegetation resembles the boreal zone, characterized by coniferous forests with a growing season of approximately 190 days per year. Dominating plant assemblages are Vaccinio uliginosi-Pinetum and Sphagno girgensohnii-Piceetum, while lake near-shore areas are overgrown by floating vegetation mats.

In the studied area, all lakes have a postglacial origin, and among them, most dystrophic lakes have a kettle form (Górniak 2006). Dystrophic lakes are shallow (at WNP, 17 lakes are shallower than $10 \mathrm{~m}$, and among them 9 lakes have $<5 \mathrm{~m}$ depth), round in shape, and have a small surface area (16 lakes are smaller than 2 ha) (Górniak 2006). The high level of suspended humic substances in the water decreases water transparency and results in brown-colored water.

\section{Methods}

Surface sediment samples (the upper-most $2 \mathrm{~cm}$, representing the most recent years of sedimentation) were collected from 18 of the 19 dystrophic lakes in the Wigry National Park in 

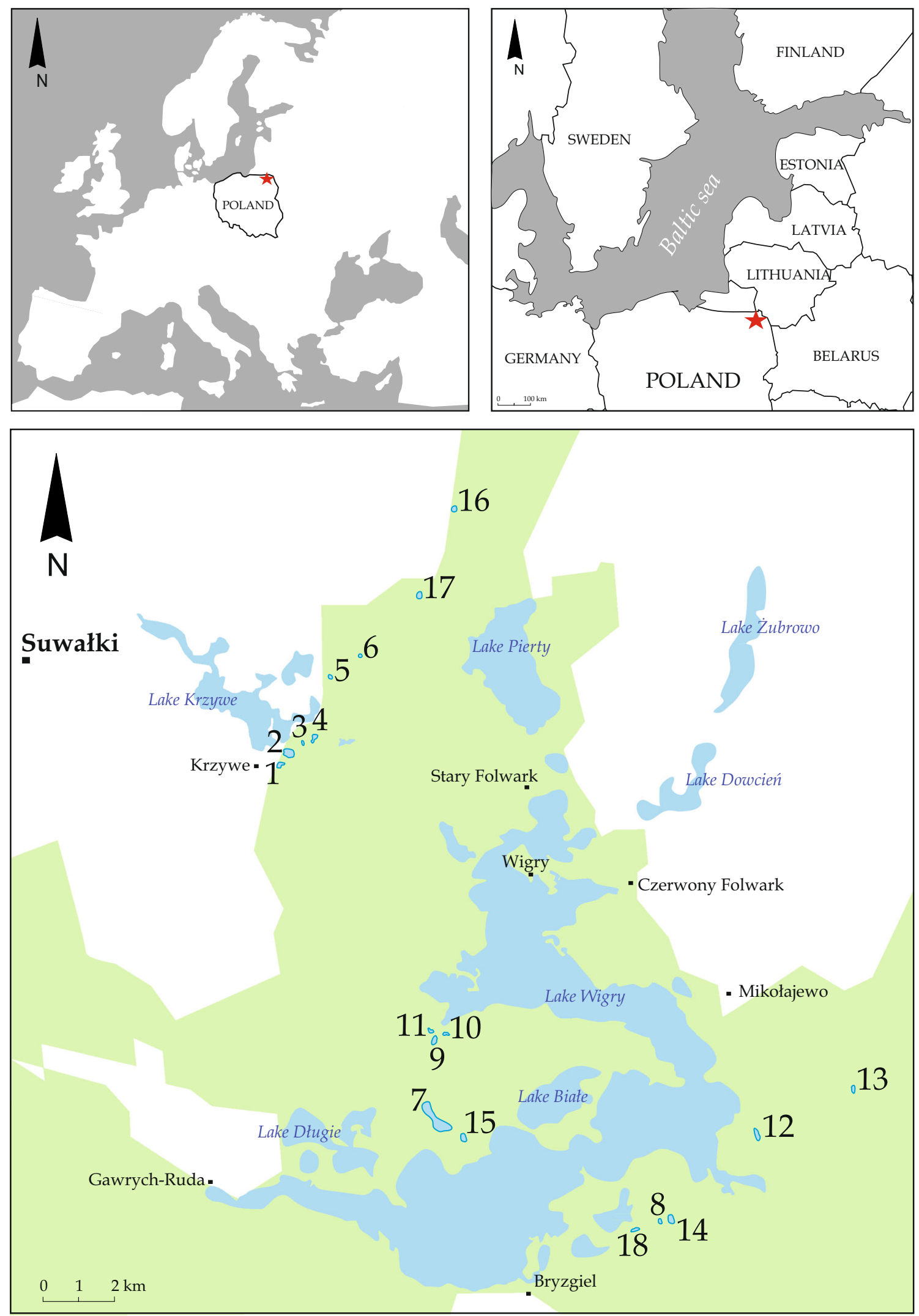

Fig. 1 Study area. Location of the studied lakes in Wigry National Park (WNP), Northeast Poland. 1- Suchar I; 2- Suchar II; 3- Suchar III; 4Suchar IV; 5 - Suchar VI; 6- Suchar VII; 7- Suchar Wielki; 8Sucharek k. Bryzgla; 9- Suchar Dembowskich; 10- Suchar Wschodni;
11- Suchar Zachodni; 12- Wygorzele; 13- Konopniak; 14- Widne; 15Suchar Rzepiskowy; 16- Pietronajć; 17- Wądołek; 18- Ślepe. Green colour on the map indicates forested areas 
July 2012, using a Kajak gravity corer. Sediment samples were taken at the deepest point $(\mathrm{P})$ and within the littoral zone (L) of lakes. Such collection of sediment sampling contains remains of all chydorids species (Chydoridae, Cladocera) that live in the lake (Frey 1960). Lakes with a maximum depth of $<3$ m (Ślepe, Suchar Zachodni, Suchar Wschodni, Suchar VII) were sampled only for littoral sediments (L), whereas small and deep lakes (Suchar IV, Suchar Dębowskich, Pietronajć, Wądołek) were sampled only at the deepest point (P). Only 10 lakes were sampled for both P and L (Table 1). Wet sediment samples from each sampling point were homogenized, placed in sterilized plastic containers and kept cool.

Physical and chemical variables of lake surface water (temperature, $\mathrm{pH}$, conductivity, dissolved oxygen) were measured in situ using WTW Multiline F/SET-3. A Secchi disk was used to measure water transparency and GPSmap 62stc to determine the sampling location. All measurements were performed around midday.

Samples for subfossil Cladocera analysis were prepared at the Bioindicators Laboratory of Warsaw Research Center, Institute of Geological Sciences, according to standard methods (Frey 1986). Sediments were heated and stirred in a $10 \%$ solution of $\mathrm{KOH}$ for $20-30 \mathrm{~min}$ and washed through a $38-\mu \mathrm{m}$ sieve. Then, samples were analysed using an OLYMPUS BX 40 transmitted-light microscope at magnifications of $100 \times$ to $400 \times$. All Cladocera remains were counted (headshields, shells, ephippia, postabdomens and postabdominal claws) and the most abundant body part of each species was considered to be representative of the number of individuals, with a minimum of 200 individuals counted per sample. Identification and nomenclature of Cladocera remains were based on Szeroczyńska and SarmajaKorjonen (2007). The results were plotted in a relative abundance diagram using C2 (Juggins 2005, 2007).

The results of the subfossil Cladocera analysis were submitted to a non-metric multidimensional scaling (NMDS) (Legendre and Legendre 1998) to elaborate on the similarities among samples in cladoceran-community composition. Composition similarities of cladoceran communities among samples NMDS was preferred over other methods (e.g., Principal Components Analysis) because it neither requires normality of the data nor linear species-environment relationships (Borcard and Legendre 2011). This method generates an ordination in a two-dimensional space where samples are grouped together according to their original descriptors (species abundances), and attempts to preserve the original topologic relationships among them. Thus, samples with similar scores in both axes of the ordination are expected to have similarities in terms of both species composition and structure of the community. Additionally, samples were grouped using cluster analysis to understand better and confirm the results of the NMDS. Given the presence of rare species that results in abundant zero-values in the dataset, Canberra distance was preferred over other distance methods, and clustering was based on furthest neighbour grouping (Correa-Metrio et al. 2011). Lastly, abundance of each species was modelled as a function of the measured environmental variables through non-parametric, locally weighted regressions (loess) (Cleveland and Devlin 1988). Combining subfossil assemblages with modern water parameters is a procedure widely acknowledged as an appropriate for determining the relationship between species and environment factors (Juggins and Telford 2012; Cwynar et al. 2012). All statistical analyses were performed in R (R Core Team 2014).

\section{Results}

\section{Water Parameters and Environmental Variables}

During the sampling campaign (July 2012), the highest water transparency was recorded at Suchar Rzepiskowy $(2.8 \mathrm{~m})$ and Suchar Wielki $(2.55 \mathrm{~m})$ lakes. Conversely, the lowest water transparency was measured at lakes Ślepe $(0.4 \mathrm{~m})$, Suchar Zachodni $(0.45 \mathrm{~m})$, Wygorzele $(0.5 \mathrm{~m})$, Sucharek k. Bryzgla $(0.6 \mathrm{~m})$, and Suchar IV $(0.65 \mathrm{~m})$. The surface water temperatures ranged from 19.5 to $28.8^{\circ} \mathrm{C}$ and were generally higher in the littoral zones. The amount of dissolved oxygen measured at 1-m water depth ranged from $7.2 \mathrm{mg} \mathrm{L}^{-1}$ at Suchar VII to $17.1 \mathrm{mg} \mathrm{L}^{-1}$ at Suchar I. Lake water ranged between acidic (pH 4.6 - Suchar IV) and neutral (pH 7.0 - Widne and Suchar Rzepiskowy). Conductivity was very low and ranged from 10 $\mu \mathrm{S} \mathrm{cm}{ }^{-1}$ (Suchar VII) to $39 \mu \mathrm{S} \mathrm{cm}^{-1}$ (Widne) (Table 1). Lake water conductivity was, in general, similar to the conductivity of regional rainwater (Hrynkiewicz and Przybylska 1994).

\section{Subfossil Cladocera}

Cladocera remains in the surface sediments of the studied lakes represented 24 species belonging to four families (Chydoridae, Bosminidae, Daphniidae, Sididae) (Fig. 2). Chydoridae was the most diverse family (18 species), whereas the other families were represented by few species (Bosminidae 3, Daphniidae 2, and Sididae 1). Cladocera concentration (individuals per $\mathrm{cm}^{3}$ ) varied from 12,677 at Suchar IV to 1888 at Suchar Wschodni (mean 5552). In four lakes (Suchar VI, Suchar VII, Sucharek k. Bryzgla, Wygorzele), only littoral Cladocera species were present, whereas in the other four lakes, littoral species reached $98 \%$. Planktonic Cladocera were dominant in lakes: Widne $(43.7 \%)$, Waidołek (26.7 \%) and Suchar I (24.7 \%) (Fig. 2). The highest Cladocera species richness was recorded in Suchar II (19), and Suchar I and Wielki (17), whereas the lowest species richness corresponded to Suchar VII (7) and Wygorzele (9) (mean 13). The Cladocera species present in all lakes were Alonella nana, 


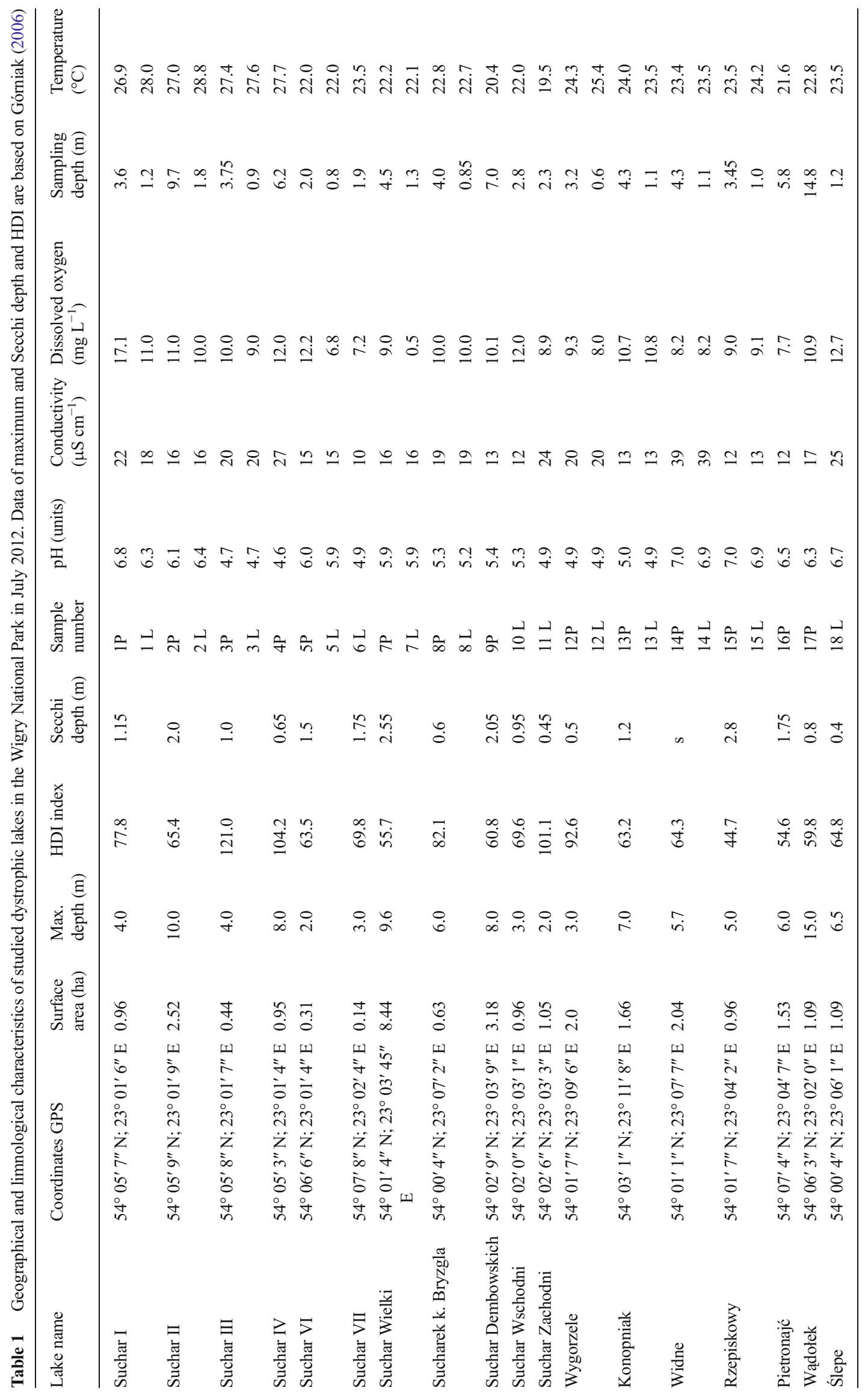




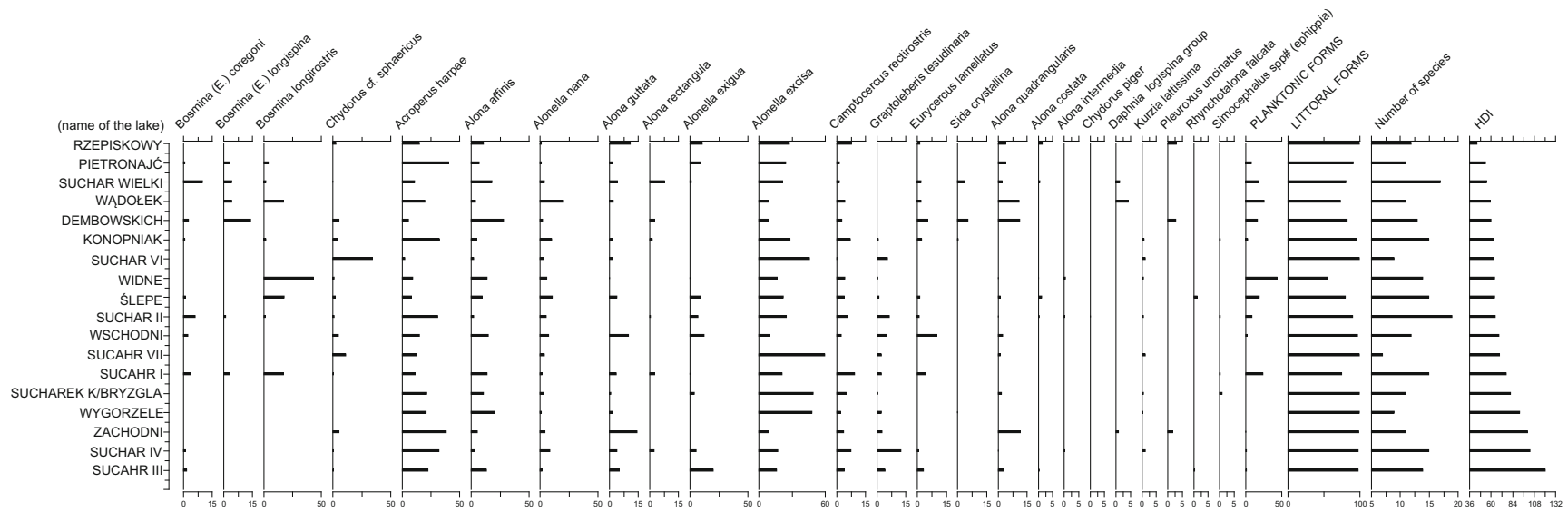

Fig. 2 Mean abundances of Cladocera in combined samples (samples taken from deepest part of the lake and from the littoral zone) in surface sediments of dystrophic lakes located in Wigry National Park. Lakes are ordered according to increasing HDI value

Acroperus harpae, and Alonella excisa, whereas Alona affinis and Camptocercus rectirostris were present in 17 out of 18 lakes (Table 2). Eight Cladocera taxa with maximum relative abundances $<2 \%$ or a presence in less than 4 lakes were found, and were considered rare. This was the case of Chydorus piger (one lake, Suchar II - $0.2 \%$ ),

Table 2 Mean and maximum relative abundance of Cladocera taxa in dystrophic lakes of the. 3 Wigry National Park. (n) Indicate number of lakes where specific Cladocera taxon was 4 found.

\begin{tabular}{|c|c|c|c|c|}
\hline Taxon & $\mathrm{n}$ & $\operatorname{Mean}(\%)$ & Maximum (\%) & SD \\
\hline Acroperus harpae & 18 & 19.69 & 40.98 & 11.46 \\
\hline Alonella nana & 18 & 5.71 & 20.00 & 4.67 \\
\hline Alonella excisa & 18 & 26.20 & 49.75 & 16.33 \\
\hline Alona affinis & 17 & 11.06 & 28.57 & 7.43 \\
\hline Camptocercus rectirostris & 17 & 4.46 & 9.71 & 2.70 \\
\hline Alona guttata & 15 & 4.57 & 10.26 & 4.20 \\
\hline Chydorus sphaericus & 14 & 5.75 & 34.94 & 8.17 \\
\hline Alona quadrangularis & 14 & 3.99 & 11.65 & 4.05 \\
\hline Graptoleberis testudinaria & 13 & 3.81 & 12.88 & 3.34 \\
\hline Alonella exigua & 11 & 7.60 & 20.31 & 6.00 \\
\hline Eurycercus lamellatus & 11 & 3.30 & 5.71 & 2.68 \\
\hline Bosmina (E.) coregoni & 10 & 3.23 & 10.37 & 4.52 \\
\hline Kurzia lattissima & 9 & 0.78 & 1.29 & 0.50 \\
\hline Bosmina longirostris & 8 & 13.45 & 18.31 & 11.50 \\
\hline Bosmina (E.) longispina & 6 & 5.22 & 14.29 & 3.55 \\
\hline Alona rectangula & 6 & 3.09 & 8.08 & 2.06 \\
\hline Alona costata & 6 & 0.82 & 1.60 & 0.50 \\
\hline Sida crystallina & 5 & 2.07 & 5.71 & 1.55 \\
\hline Pleuroxus uncinatus & 4 & 1.99 & 3.16 & 1.04 \\
\hline Simocephalus spp. (ephippia) & 4 & 0.58 & 1.12 & 0.29 \\
\hline Alona intermedia & 3 & 0.47 & 0.64 & 0.19 \\
\hline Daphnia longispina group & 8 & 2.30 & 4.44 & 1.09 \\
\hline Rhynchotalona falcata & 2 & 0.96 & 1.41 & 0.35 \\
\hline Chydorus piger & 1 & 0.18 & 0.18 & 0.04 \\
\hline
\end{tabular}

Rhynchotalona falcata (two lakes, Suchar III - $0.5 \%$, Ślepe - $1.4 \%$ ), Alona intermedia (three lakes, Suchar II - $0.4 \%$, Suchar - IV $0.4 \%$, Widne - $0.6 \%$ ), Daphnia longispina group (three lakes, Suchar Wielki - 1.5\%, Suchar Zachodni - $1.0 \%$, Wadołek - $4 \%$ ), Pleuroxus uncinatus (three lakes, Suchar Dębowskich - $2.9 \%$, Suchar Zachodni - $1.9 \%$, Suchar Rzepiskowy $-3.2 \%$ ), and Simocephalus sp. (four lakes, Suchar I - $0.4 \%$, Suchar II $-0.4 \%$, Sucharak k. Bryzgla $1.1 \%$, Konopniak - $0.5 \%$ ). Kurtzia latissima and Alona costata were present at eight and six lakes, respectively, but their relative abundances were less than $1.6 \%$ (Fig. 2).

\section{Statistical Analysis}

NMDS produced an ordination with quadrant I being occupied exclusively by littoral samples, quadrant IV occupied by pelagic samples (except one), and quadrants II and III showing a mixture of both sample provenances (Fig. 3). Alternatively, the cluster dendrogram showed a mixture of both provenances (littoral and pelagic) in all groups (Fig. 3). Defining a cutting threshold of 21 distance units, three groups formed in the cluster dendrogram. Group one had eight samples from five lakes: Widne $(\mathrm{P}+\mathrm{L})$, Sucharek k. Bryzgla $(\mathrm{P}+\mathrm{L})$, Wygorzele $(\mathrm{P}+\mathrm{L})$, Suchar VI $(\mathrm{P})$, and Suchar VII $(\mathrm{L})$. Group two contained fourteen samples from ten lakes: Suchar I $(P+L)$, Suchar II $(\mathrm{P}+\mathrm{L})$, Suchar II $(\mathrm{P}+\mathrm{L})$, Konopniak $(\mathrm{P}+\mathrm{L})$, Suchar IV (P), Pietronajć (P), Suchar Dembowskich (P), Suchar Wielki (P), Suchar Wschodni (L), and Ślepe (L). Group three contained six samples from lakes Suchar Wielki (L), Wądołek (P), Suchar VI (L), Suchar Zachodni (L), and Rzepiskowy $(\mathrm{P}+\mathrm{L})$. The first group was confirmed by samples that were ordinated on the positive side of Axis 1 in the NMDS (red dots in Fig. 3), whereas samples in the second group were mostly located on the negative side of NMDS Axis 1 (black dots in Fig. 3). Alternatively, samples that were in the third cluster group were scattered 
Fig. 3 Non-metric multidimensional scaling (NMDS) of Cladocera samples from dystrophic lakes at the Wigry National Park. Samples coded according to their provenance (littoral and pelagic, upper panel) and according to the group they belong in the cluster analysis (lower panel)
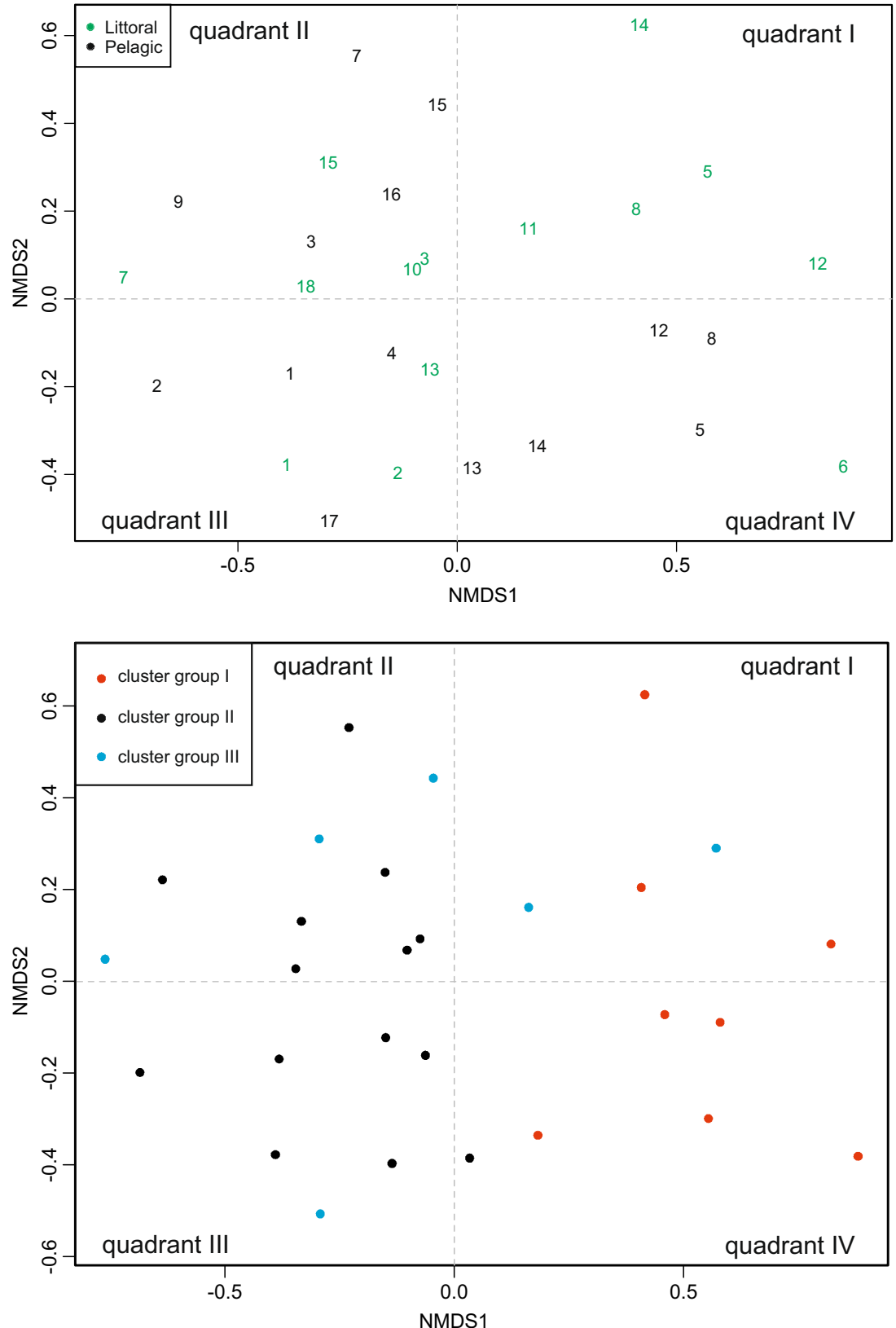

throughout the NMDS biplot (blue dots in Fig. 3). These results suggest that although sample provenance plays an important role at structuring the cladoceran community, other factors are likely more determining.

According to loess regressions, some Cladocera taxa at dystrophic lakes in the Wigry National Park were dependent on measured environmental variables (Fig. 5). Three species (Alona rectangula, Daphnia longispina group, Chydorus cf. sphaericus) were dependent on lake size (area), and two of them (Daphnia longispina group, Chydorus cf. sphaericus) were dependent on the lake maximum depth. The abundance of Alona rectangula showed a positive relationship with lake size, and the Daphnia longispina group, with lake size and depth. Conversely, Chydorus cf. sphaericus was negatively associated with lake size, depth and conductivity (Fig. 5a, b and d). A positive relationship was found between Bosmina longirostris and the water conductivity (Fig. 5b). The water oxygen was an important variable at explaining the distribution of Daphnia longispina group and Alona costata (Fig. 5e), both of the species displaying a negative response to a decrease in Dissolved Oxygen. Species belonging to Eubosmina group and Eurycercus lamellatus decreased in medium oxygen values (5-10 $\mathrm{mg} \mathrm{L}^{-1}$ ) and increased in well-oxygenated waters (>10 $\mathrm{mg} \mathrm{L}^{-1}$ ). Water transparency had a substantial influence on the abundance of Rhynchotalona falcata and Pleuroxus trigonellus, both littoral species (Fig. 5c). Whereas the former 
decreased with water transparency, the latter increased. One of the most interesting environmental characteristics of dystrophic lakes is their $\mathrm{pH}$, which explained the distribution of five Cladocera taxa (Fig. 5f). The most acidic-condition tolerating species were Alonella exigua, Graptoleberis testudinaria, Acroperus harpae, and Alonella nana, although the two latter species also showed high abundances at high $\mathrm{pH}$. The high relative abundance of these species within sites at $\mathrm{pH}$ lower than 5.5 suggests a high tolerance to acidic conditions. Alternatively, neutral waters were preferred by Bosmina longirostris, which also increased in abundance with an increase in $\mathrm{pH}$. In our research, the abundance of Alona affinis in lakes appeared to be independent of $\mathrm{pH}$ values (Fig. 5f).

\section{Discussion and Conclusion}

Although we covered a wide range of HDI (from 45 to 121 HDI) with our sampling design, the obtained results might suggest that Cladocera species composition does not statistically depend on the HDI value. Our studies showed that Cladocera assemblages of WNP are not significantly associated with dystrophication state. This observation is especially evident in the fact that neither NMDS nor cluster produced a clear classification of the lakes. There was still a degree of mixing between lake categories in both ordinations (Figs. 3 and 4). However, it is important to notice that single Cladocera species (taxa) resulted closely associated with some environmental factors (e.g., $\mathrm{pH}$, lake size and depth, Fig. 5). Thus, even though Cladocera community structure does not directly depend on the dystrophy state, it is an emergent property of individual species responses to environmental factors that may be closely associated to it.

The obtained results suggest that dystrophication state itself creates unique and specific Cladocera species composition. In dystrophic lakes, acidity and toxicity (e.g., aluminium) of water are buffered and complexed with high contents of humic matter (Henriksen et al. 1989). Thus, the biological impact of acidification in humic lakes is generally lower and less serious compared with clear water lakes with low organic content (Keskitalo and Eloranta 1999). The effect of pH in dystrophic lakes is overshadowed by their humic character, which can explain the surprisingly high diversity and abundance of zooplankton at the studied lakes.

Our results indicate that the best representative Cladocera species for the dystrophic condition are Alonella excisa, Acroperus harpae, Alonella nana, Alona affinis and Camptocercus rectirostris. This composition is substantially different to the one associated with harmonic (non-dystrophic) shallow lakes, which in lowland Europe are typically dominated by Bosminidae spp. and Chydorus sphaericus (Milecka and Szeroczyńska 2005; Bjerring et al. 2009; MirosławGrabowska and Zawisza 2013; Nevalainen et al. 2013). These latter species were rather rare at the studied dystrophic lakes. The most abundant species at the lakes of the WNP (Alonella excisa, Acroperus harpae, Alonella nana, Alona affinis and Camptocercus rectirostris - see Table 2) have also been reported as characteristic of boreal lakes, e.g. in Scandinavia (Korhola 1999; Sarmaja-Korjonen and Alhonen 1999; Bjerring et al. 2009; Nevalainen et al. 2013). This observation reaffirms a high resemblance between the NE Poland lowlands and high latitude areas.
Fig. 4 Cluster grouping of Cladocera samples from dystrophic studied lakes at the Wigry National Park, based on Canberra distance method and the furthest neighbour linkage. Colours in cluster branches indicate cluster groups: red- group I, black- group II, blue - group III. The colour of the lake name indicates (pelagic) black and littoral (green) samples

\section{Cluster Dendrogram}

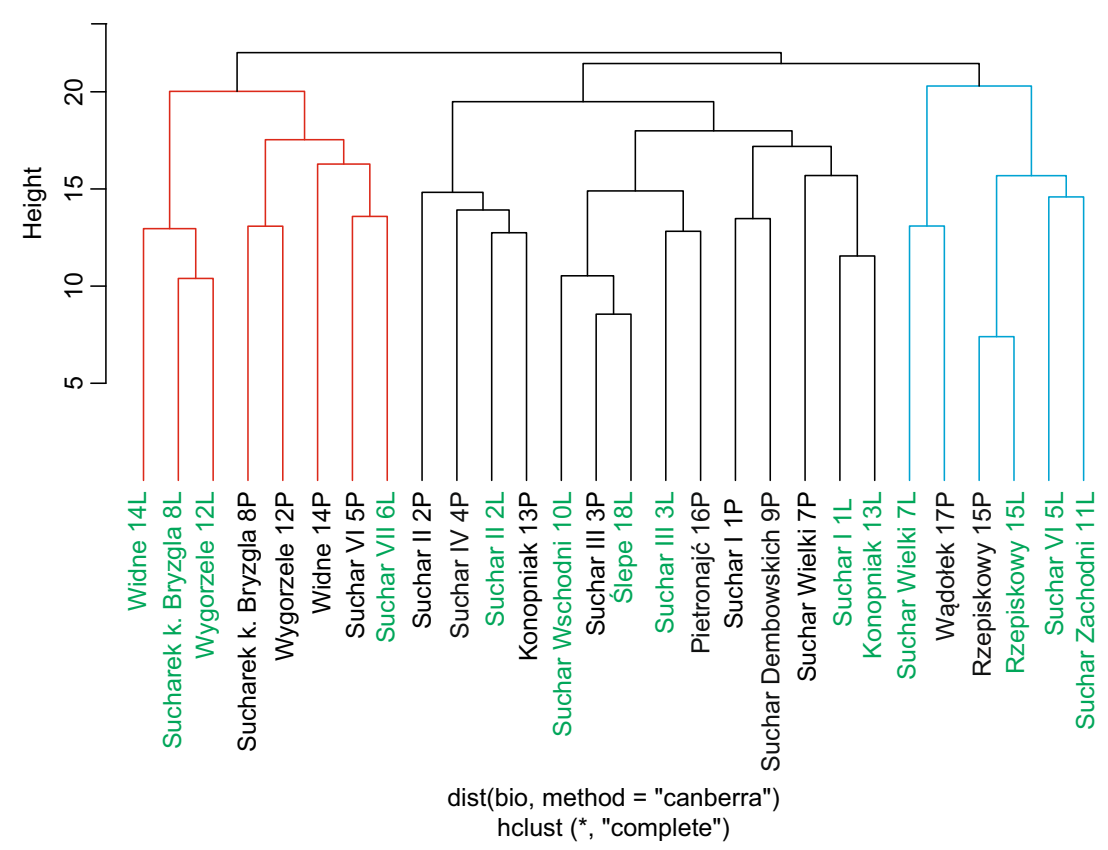




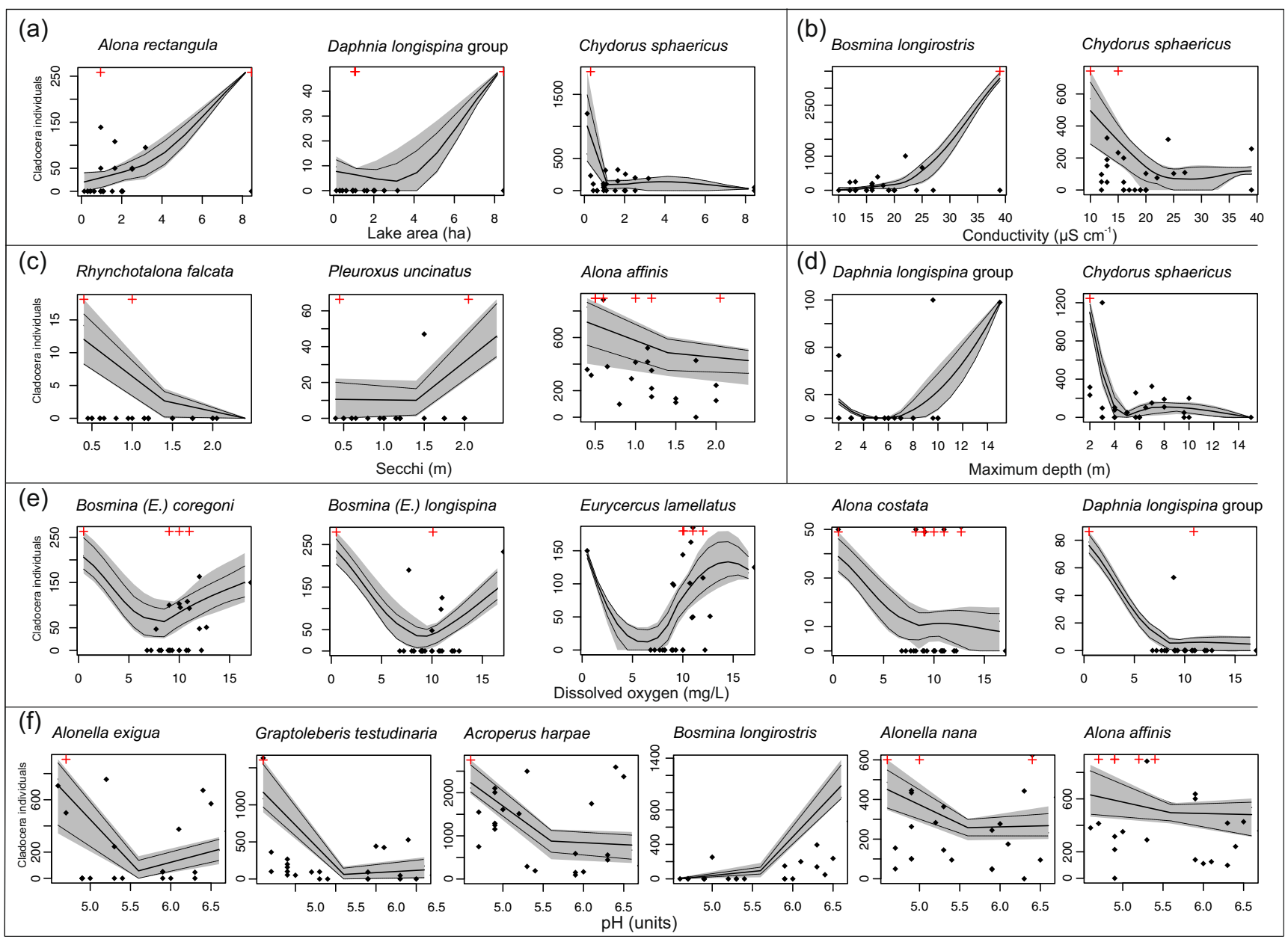

Fig. 5 Selected species abundance for each sediment sample per $\mathrm{cm}^{3}$ (diamonds with red crosses representing observations beyond the scale of y-axis) as a function of environmental factors: (a) lake area, (b) conductivity, (c) Secchi depth, (d) maximum lake depth, (e) dissolved oxygen, and (f) $\mathrm{pH}$. Species-environment variable relationships were

Alonella excisa and Acroperus harpae are considered representative of oligotrophic, low nutrient and acidic lakes (Fryer 1968, 1991; Whiteside 1970; Rautio 1998; Bjerring et al. 2009; Nevalainen et al. 2013; Zawiska et al. 2013). However, it has been suggested that these two species are also very successful in soft water lakes because of their low calcium demands $\left(\mathrm{Ca}^{+2}\right)$ (Nevalainen et al. 2013). Our results are consistent with these observations, as both species were observed to be highly tolerant to acidic conditions, and showed relatively high abundances in lakes at the higher end of the studied $\mathrm{pH}$ gradient (Fig. 5).

Alonella nana was the most frequent and abundant species in the studied samples (present in $100 \%$ of lakes). This taxon is characteristic of boreal lakes (Korhola 1999; Nevalainen et al. 2013), and has even been classified as a "subarctic" taxon (Harmsworth 1968). However, this species is also strongly phytophilous and has a marked environmental preference for dystrophic lakes with Sphagnum mosses (Fryer 1968; Duigan 1992; Nevalainen et al. 2013). On the other generalized through non-parametric, locally weighted regressions (loess) (black solid line). Regressions were fitted leaving out one observation at a time (grey area) to compute $95 \%$ confidence interval (grey lines)

hand, the occurrence of Alonella nana at the studied lakes was most likely the result of both low $\mathrm{pH}$ and the dominance of Sphagnum in the littoral zones. Moreover, the WNP is located in the coldest Polish lowland area where climate conditions are similar to Scandinavia and the southern boreal zone (McKnight and Darrel 2000; Drzymulska et al. 2013).

Alona affinis was very frequently observed and abundant in the studied lakes (17 lakes, maximum relative abundance $28 \%$ ), and it was found in lakes ranging from acidic to neutral waters (independent of $\mathrm{pH}$ value). This species is considered cold-associated and subarctic (Harmsworth 1968; Flössner 2000; Zawisza and Szeroczyńska 2007). Its occurrence in WNP further notes to the boreal character of the area. The apparent success of Alona affinis populations in these dystrophic lakes could also be related to their ability to survive in medium depth waters (Nevalainen 2011), where they feed on detritus (Flössner 2000; de Eyto and Irvine 2001; Nevalainen et al. 2013). These abilities allow Alona affinis to have a significant advantage over other species in 
lacustrine environments (Nevalainen et al. 2013). Additionally, the presence of the comparatively rare and never numerous species Camptocercus rectirostris (Smirnov 1998) in 17 from 18 studied lakes was a significant finding. This species prefers detritus-covered habitat with a presence of macrophytes (Fryer 1968, 1991) - environmental conditions that are offered by dystrophic lakes.

Chydorus cf. sphaericus was present in 14 lakes, but its relative abundances were low (in 9 lakes lower than $5 \%$, only in two lakes the abundances were more than $10 \%$ ) (Fig. 2). This taxon is one of the most widespread species across Europe and is known for its wide ecological tolerance, especially to pH (Walseng et al. 2003; Belyaeva and Deneke 2007; Zawisza and Cedro 2012). Thus, its low abundance was surprising, and this finding is probably the result of the uniqueness of this area where temperate and boreal conditions conjugate.

Planktonic species found in the sediment of the WNP lakes were represented by Eubosmina [Bosmina (E.) longispina, Bosmina (E.) coregoni], Bosmina longirostris and Daphnia longispina group. The highest abundances of Eubosmina (>5 \%) and Daphnia $(4.4 \%)$ were realized at the deepest $(>8 \mathrm{~m}$ ) and biggest lakes, confirming their preference for deep and nutrient-poor lakes (Fryer 1985; Korhola 1999; Brancelj et al. 2009). However, their relative abundances were rather low (Table 2), suggesting that dystrophic environments are not optimal for their development. Daphnia longispina group is also known for its low tolerance to acidic waters, being incapable of surviving at the low $\mathrm{pH}$ that characterizes dystrophic lakes; pH 5.5 is considered the lower limit for this taxa (Alibone 1981, Weber and Pirow 2009). The occurrence of Daphnia (in 3 lakes) and Eubosmina (in 11 lakes) at very low relative abundances was likely more associated with the morphometry of the studied lakes (small and shallow) than with dystrophic conditions. However, low Daphnia percentages may have also been linked with very low calcium content in the water of the lakes, an environmental condition that is critical for the development of most species belonging to this genus (Jeziorski et al. 2008; Shapiera et al. 2011).

In all planktonic species, the highest relative abundances were reached by Bosmina longirostris (mean $13.45 \%$ ). This is the smallest species of the Bosminidae family, and it has the ability to live either in the planktonic zone or among macrophytes (Cerbin et al. 2003; Nevalainen 2011). Its highest relative abundances in the studied lakes were associated with neutral to nearly neutral pH (Fig. 5f) and a high conductivity (Fig. 5b). According to Locke and Sprules (2000), Bosmina longirostris is decidedly better adapted to neutral conditions than to acidic ones, but it tolerates low $\mathrm{pH}$.

Cladocera species composition of the dystrophic lakes in the WNP is very similar to that observed in boreal dystrophic lakes at the North Hemisphere [Scandinavia (Rautio 2001;
Nevalainen et al. 2013), North America (Korosi and Smol 2011), and Russia (Smirnov 1971)]. Our results prove that the studied lakes have much a higher Cladocera species richness than it was previously thought and reported (Kostro 1990, Tunowski 1992, Górniak and Dobrzyń 1999, Karabin 1999). We demonstrate that the cladoceran community at the WNP dystrophic lakes is quite diverse and is represented by at least 24 species. The difference between the previously reported diversity and that reported here is likely the result of the research methods used. In previous studies, samples were collected using plankton net once a year, resulting in a temporally and spatially biased collection. Our sedimentbased study offers a better representation of species richness, as the mud-water interface contains remains of Cladocera collected through several seasons and composed of benthic and planktonic species. Furthermore, we expect Cladocera species richness in the study area to be even higher than that reported here because the remains of several planktonic species, such as: Scapholeberis sp., Simocephalus sp., do not preserve in the sediments.

Overall, our results show a cladoceran community more diverse and abundant than previously thought. The composition and structure of the studied Cladocera assemblages resemble those of the boreal region, reflecting the climatic disconnect that exists between the Polish lowlands and similar environments is the rest of Europe. Given the extreme environmental conditions, the diversity and composition found in the studied samples was surprising, and according to our analyses at species and community levels, community assemblage is not directly associated with dystrophy. Rather, community properties in the region, although highly affected by $\mathrm{pH}$, seem to emerge from the individual species response to other environmental drivers (conductivity, water transparency, lake morphology, dissolved oxygen, among others). Likely, humic acids play a major role in buffering environmental harshness, ameliorating conditions in such a way that cladoceran populations are viable in space and time.

Acknowledgments This study was founded by the Polish Ministry of Science (Grant no. N N306 228039). The Izabela Zawiska work on this manuscript was supported by and the Virtual Institute of Integrated Climate and Landscape Evolution Analysis (ICLEA) of the Helmholtz Association. The accomplishment of this research was possible only with the support of the Institute of Geological Sciences and Institute of Geography and Spatial Organization of Polish Academy of Sciences and employees of Wigry National Park, especially Lech Krzysztofiak.

Open Access This article is distributed under the terms of the Creative Commons Attribution 4.0 International License (http:// creativecommons.org/licenses/by/4.0/), which permits unrestricted use, distribution, and reproduction in any medium, provided you give appropriate credit to the original author(s) and the source, provide a link to the Creative Commons license, and indicate if changes were made. 


\section{References}

Alibone MR (1981) The effects of low pH on the respiration of Daphnia magna Straus. Hydrobiology 85(2):185-188

Amsinck SL, Jeppesen E, Landkildehus F (2005) Relationships between environmental variables and zooplankton subfossils in the surface sediments of 36 shallow coastal brackish lakes with special emphasis on the role of fish. J Paleolimnol 33:39-51

Belyaeva M, Deneke ER (2007) Colonization of acidic mining lakes: Chydorus sphaericus and other Cladocera within a dynamic horizontal $\mathrm{pH}$ gradient ( $\mathrm{pH}$ 3.7) in Lake Senftenberger See (Germany). Hydrobiologia 594:97-108. doi:10.1007/s10750-007-9082-5

Bjerring R, Becares E, Declerck S, Gross EM, Hansson L-A, Kairesalo T, Nykänen M, Halkiewicz A, Kornijów R, CondePorcuna JM, Sereflis M, Nõges T, Moss B, Amsinck SL, Odgaard BV, Jeppesen E (2009) Subfossil cladocera in relation to contemporary environmental variables in 54 pan-European lakes. Freshw Biol 54:2401-2417

Borcard DF, Legendre GP (2011) Numerical ecology with R. Springer, New York

Brancelj A, Kernan M, Jeppesen E, Rautio M, Manca M, Šiško M, Alonso M, Stuchlík E (2009) Cladocera remains from the sediment of remote cold lakes: a study of 294 lakes across Europe. Adv Limnol 62:269-294

Brodersen KP, Whiteside MC, Lindegaard C (1998) Reconstruction of trophic state in Danish lakes using subfossil chydorid (cladocera) assemblages. Can J Fish Aquat Sci 55:1093-1103

Cerbin B, Balayla DJ, Van de Bund WJ (2003) Smallscale distribution and diel vertical migration of zooplankton in a shallow lake (Lake Naardermeer, the Netherlands). Hydrobiologia 491:111-117

Chen G, Dalton C, Taylor D (2010) Cladocera as indicators of trophic state in Irish lakes. J Paleolimnol 44:465-481

Cleveland WS, Devlin SJ (1988) Locally weighted regression: an approach to regression analysis by local fitting. J Am Stat Assoc 83: 596-610

Core Team R (2014) R: a language and environment for statistical computing. R Foundation for Statistical Computing, Vienna www.r-project.org

Correa-Metrio A, Bush M, Pérez L, Schwalb A, Cabrera KR (2011) Pollen distribution along climatic and biogeographic gradients in northern central America. The Holocene 21:681-692

Cwynar LC, Rees ABH, Pedersen CR, Engels S (2012) Depth distribution of chironomids and an evaluation of site-specific and regional lake-depth inference models: a good model gone bad? J Paleolimnol 48:517-533

de Eyto E, Irvine K (2001) The response of three chydorid species to temperature, $\mathrm{pH}$ and food. Hydrobiologia 459:165-172

Drzymulska D, Zieliński P (2013) Developmental changes in the historical and present-day trophic status of brown water lakes. Are humic water bodies a uniform aquatic ecosystem? Wetlands 33:909-919. doi:10.1007/s13157-013-0452-7

Drzymulska D, Kłosowski K, Pawlikowski P, Zieliński P, Jabłońska E (2013) The historical development of vegetation of foreshore mires beside humic lakes: different successional pathways under various environmental conditions. Hydrobiologia 703:15-31. doi:10.1007/s10750-012-1334-3

Duigan CA (1992) The ecology and distribution of the littoral freshwater Chydoridae (Branchiopoda, Anomopoda) of Ireland, with taxonomic comments on some species. Hydrobiologia 241:1-70

Flössner D (2000) Die Haplopoda und Cladocera (ohne Bosminidae) Mitteleuropas. Backhuys Publishers, Leiden

Frey DG (1960) On the occurrence of cladoceran remains in Lake sediments. Proceedings of the National Academy of Sciences USA 46(6):917-920
Frey DG (1986) Cladocera analysis. In : BE Berglund (ed) Handbook of Holocene palaeoecology and palaeohydrology. John Wiley \& Sons Ltd, Chichester

Fryer G (1968) Evolution and adaptive radiation in the Chydoridae (Crustacea: cladocera): a study in comparative functional morphology and ecology. Philosophical transactions of the Royal Society of London. Series B, Biological Sciences 254:221-382

Fryer G (1985) The ecology and distribution of the genus daphnia (Crustacea: cladocera) in restricted areas: the pattern in Yorkshire. J Nat Hist 19:97-128

Fryer G (1991) Functional morphology and the adaptive radiation of the Daphniidae (Branchiopoda Anomopoda). Philosophical transactions of the Royal Society of London. Series B, Biological Sciences 331:1-99

Gałka M, Tobolski K, Zawisza E, Goslar T (2014) Postglacial history of vegetation, human activity, and lake-level changes at Lake Linówek in Northeast Poland, based on multiproxy data. Veg Hist Archaeobotany 23:123-152. doi:10.1007/s00334-013-0401-7

Górniak A (1996) Substancje humusowe i ich rola w funkcjonowaniu ekosystemów słodkowodnych. Dissertationes Universitatis Varsoviensis, Białystok

Górniak A (2006). Jeziora Wigierskiego Parku Narodowego. Aktualna jakość i trofia wód. Wydawnictwo Uniwersytetu w Białymstoku

Górniak A, Dobrzyń P (1999). Zooplankton skorupiakowy trzech jezior dystroficzncyh Wigierskiego Parku Narodowego. Zdanowski (ed) Funkcjonowanie i ochrona ekosystemów wodnych na obszarach chronionych, 435-447

Grabowska-Bajkiewicz E (1997) Charakterystyka fizycznogeograficzna zlewni eksperymentalnej Wigierskiej Stacji Bazowej. In: Krzysztofiak L (ed) Zintegrowany Monitoring Srodowiska Przyrodniczego. Stacja Bazowa Wigry (Wigierski Park Narodowy). Biblioteka Monitoringu Srodowiska, Suwałki

Harmsworth RV (1968) The development history of Blelham Tarn (England) as show by animals microfossils, with special reference to the cladocera. Ecol Monogr 38:223-241

Henriksen A, Lien L, Rosseland BO, Traaen TS, Sevaldrud IS (1989) Lake acidification in Norway - present and predicted fish status. Ambio 18:314-321

Hrynkiewicz R, Przybylska G (1994). Analiza aktualnych i spodziewanych zmian zanieczyszczenia atmosfery w pólnocno-wschodniej Polsce. In Hillbricht-Iłkowska, A. \&R.J. Wiśniewski (eds). Jeziora Suwalskiego Parku Krajobrazowego. Komitet Nauk. PAN, Człowiek i Środowisko 7:73-102

Jeziorski A, Yan ND, Paterson AM, DeSellas AM, Turner M, Jeffries DS, Keller B, Weeber RC, McNicol DK, Palmer ME, McIver K, Arsenau K, Ginn BK, Cumming BF, Smol JP (2008) The widespread threat of calcium decline in fresk waters. Science 322: 1374-1377

Jones RI (1992) The influence of humic substances on lacustrine planktonic food chains. Hydrobiologia 229:73-91

Juggins S (2005) New features in C2 version 1.4. University of Newcastle, Newcastle

Juggins S (2007) User guide C2 Software for ecological and palaeoecological data analysis and visualisation User guide Version 1.5. University of Newcastle, Newcastle

Juggins S, Telford RJ (2012) Exploratory data analysis and display. In: Birks HJB, Lotter AF, Juggins S, Smol JP (eds) Tracking environmental change using Lake sediments: data handling and statistical techniques. Springer, Dordrecht, pp. 123-142

Karabin A (1999). Zespoły Crustacea strefy przybrzeżnej humusowych jezior Wigierskiego Parku Narodowego. Zdanowski (ed) Funkcjonowanie i ochrona ekosystemów wodnych na obszarach chronionych, pp 405-415

Karabin A, Ejsmont-Karabin J (1999). Jezioro Wigry - wieloletnia sukcesja zespołów Rotifera i Crustacea. Zdanowski (ed) Funkcjonowanie i 
ochrona ekosystemów wodnych na obszarach chronionych, pp 371-388

Keskitalo J, Eloranta P (1999) Limnology of humic waters. Backhuys, Leiden

Kondracki J (1994) Geografia Polski. Mezoregiony fizycznogeograficzne, Warszawa

Korhola A (1999) Distribution patterns of cladocera in subarctic Fennoscandian lakes and their potential in environmental reconstruction. Ecography 22:357-373

Korhola A, Tikkanen M, Weckstrom J (2005) Quantification of Holocene lake-level changes in Finnish Lapland using a cladocera-lake depth transfer model. J Paleolimnol 34:175-190

Korosi JB, Smol JP (2011) Distribution of cladoceran assemblages across environmental gradients in Nova Scotia (Canada) lakes. Hydrobiologia 663:83-99

Kostro J (1990) Liczebność i struktura planktonu skorupiakoweo pobrzeża jezior polihumusowych Wigierskiego Parku Narodowego. Praca magisterska, FUW Białystok

Kozłowska M (1999). Wpływ trofii na strukturę jakościową i ilościową zooplanktonu w niektórych zbiornikach Wigierskiego Parku Narodowego i jeziora Hańcza. Zdanowski (ed) Funkcjonowanie i ochrona ekosystemów wodnych na obszarach chronionych, pp 417-434

Legendre P, Legendre L (1998) Numerical Ecology. Elsevier Scientific, Oxford

Locke A, Sprules WG (2000) Effects of acidic pH and phytoplankton on survival and condition of Bosmina longirostris and Daphnia pulex. Hydrobiologia 437:187-196

Lotter AF, Birks HJB, Hofmann W, Marchetto A (1997) Modern diatom, cladocera, chironomid and chrysophyte cyst assemblages as quantitative indicators for the reconstruction of past environmental conditions in the Alps. I Climate. Journal of Paleolimnology 18:395-420

Marks L (2002) Last glacial maximum in Poland. Quat Sci Rev 21: $103-110$

McKnight TL, Darrel H (2000) Climate zones and types. Physical geography: a landscape appreciation. Prentice Hall, Upper Saddle River

Milecka K, Szeroczyńska K (2005) Changes in macrophytic flora and planktonic organisms in Lake Ostrowite, Poland, as a response to climatic and trophic fluctuations. The Holocene 15:74-84

Mirosław-Grabowska J, Zawisza E (2013) Holocene environmental changes in Charzykowskie Lake (northern Poland) based on oxygen and carbon isotopes and Cladocera data. Quaternary International 328-329:156-166. doi:10.1016/2013.07.019

Nevalainen L (2011) Intra-lake heterogeneity of sedimentary cladoceran (Crustacea) assemblages forced by local hydrology. Hydrobiologia 676:9-22. doi:10.1007/s10750-011-0707-3

Nevalainen L, Luoto TP, Kultti S, Sarmaja-Korjonen K (2013) Spatiotemporal distribution of sedimentary Cladocera (Crustacea: Branchiopoda) in relation to climate. Journal of Biogeography 40: 1548-1559. doi:10.1111/jbi.12101
Rautio M (1998) Community structure of crustacean zooplankton in subarctic ponds - effects of altitude and physical heterogeneity. Ecography 21:327-335

Rautio M (2001) Zooplankton assemblages related to environmental characteristics in treeline 580 ponds in Finnish Lapland. Arct Antarct Alp Res 33:289-298

Rumes B, Eggermont H, Verschuren D (2011) Distribution and faunal richness of cladocera in western Uganda crater lakes. Hydrobiologia 676:39-56. doi:10.1007/s10750-011-0829-7

Sarmaja-Korjonen K, Alhonen P (1999) Cladoceran and diatom evidence of lake-level fluctuations from Finnish lake and the effect of aquaticmoss layers on microfossil assemblages. J Paleolimnol 22:277-290

Shapiera M, Jeziorski M, Yan ND, Smol JP (2011) Calcium content of littoral cladocera in three softwater lakes of the Canadian shield. Hydrobiologia 678:77-83

Smirnov NN (1971) Chydoridae. Fauna of the U.S.S.R. Wiley, Sussex

Smirnov NN (1998) A revision of the genus Camptocercus (Anomopoda, Chydoridae, Aloninae). Hydrobiologia 386:63-83

Szeroczyńska K (1991) Impact of prehistoric settlements on the Cladocera in the sediements of Lake Suszek, Błędowo and Skrzetuszewskie. Hydrobiologia 225:105-114

Szeroczyńska K, Sarmaja-Korjonen K (2007) Atlas of subfossil cladocera from central and northern Europe. Friends of the Lower Vistula Society

Tunowski J (1992). Zooplankton jezior dystroficznych WPN In: Zdanowski 1992: Jeziora Wigierskiego Parku Narodowego. Zeszyty Naukowe 3. Polska Akademia Nauk

Walseng B, Yan ND, Schartau AK (2003) Littoral microcrustacean (cladocera and Copepoda) indicators of acidification in Canadian shield lakes. Ambio 32:208-213

Weber AK, Pirow R (2009) Physiological responses of Daphnia pulex to acid stress. BMC Physiology 9(9):1-25

Whiteside MC (1970) Danish chydorid cladocera: modern ecology and core studies. Ecol Monogr 40:79-118

Zawiska I, Zawisza E, Woszczyk M, Szeroczyńska K, Spychalski W, Correa-Metrio A (2013) Cladocera and geochemical evidence from sediment cores show trophic changes in polish dystrophic lakes. Hydrobiologia 715:181-193. doi:10.1007/s10750-013-1482-0

Zawiska I, Słowiński M, Correa-Metrio A, Obremska M, Luoto T, Nevalainen L, Woszczyk M, Milecka K (2015) The response of a shallow lake and its catchment to late glacial climate changes - a case study from eastern Poland. Catena 126:1-10. doi:10.1016/j. catena.2014.10.007

Zawisza E, Cedro B (2012) Subfossil cladocera (Crustacea) fauna from sediments of Samowo drainage paleochannels (core T28). In: Cedro B (ed) Późnoglacjalne i holoceńskie przemiany środowiska przyrodniczego zarejestrowane w osadach profilu T28 z okolic Mrzeżyna na podstawie badań wielodyscyplinarnych. Wydawnictwo ZAPOL, Szczecin

Zawisza E, Szeroczyńska K (2007) The development history of Wigry Lake as shown by subfossil cladocera. Gochronometria 27:67-74. doi: 10.2478/v10003-007-0021-2 